A publication of the Muma College of Business | University of South Florida

\title{
A DISTRICT APPROACH TO SMART MOBILITY ${ }^{1}$
}

"As a Smart City district evolves, and its success as a business location of choice grows, we need to ensure that mobility challenges are addressed for all communities. Smart technologies are a major factor." - Ronan Herron

Ronan Herron had recently been appointed the Smart Dublin Coordinator with responsibility for Smart Sandyford and was travelling to its launch on the modern Luas light rail system. Ronan found himself marvelling at the changes to the Sandyford area since he first started working in the Council twelve years earlier: Gone was the old industrial landscape with pockets of sad-looking housing estates, and in its place was a vibrant business district with multiple household name multinational companies, nestled with modern residential areas. Sandyford was a short distance from Dublin city centre but just ten short years prior, few would have anticipated the economic and business transformation that had overcome this once maligned and side-lined district of Dublin.

While Ronan had managed to get a seat on the packed Luas tram, he noticed multiple congested areas in and around the route to the launch. Clearly, this had become a very popular district indeed. Since starting in his post, Ronan had observed that the Dún Laoghaire Rathdown County Council (DLR), a funding partner for Smart Sandyford, was very excited about the future for the Sandyford district, anticipating (and indeed, planning for) significant growth in the number of businesses moving there, and additional residential areas. Ronan contemplated what impact this was likely to have on on-going mobility for everyone living and working in the district.

This Smart District offered a means to answer some of the pressing questions around mobility for Dublin: How might technology deployment improve mobility services? How would mobility solutions impact stakeholders in the community? Can technology alleviate the impact of transport on the environment? What data would even be needed? How would the data needed to enable smart mobility be collected and analysed?

With the first case of the Covid-19 virus detected in Ireland that week all of the agreed plans had to be reviewed. Given his background in smart technologies, and the expertise of the Smart Sandyford partners, Ronan naturally found himself contemplating what could be achieved during this time of crisis and how technology could overcome this adversity to address Sandyford's growing mobility challenges.

\footnotetext{
${ }^{1}$ Copyright (C) 2021, Conor Mark Dowling, Matt Mullarkey \& Siobhán Clarke. This case was prepared for the purpose of class discussion, and not to illustrate the effective or ineffective handling of an administrative situation. Names and some information have been disguised. This case is published under a Creative Commons BY-NC license. Permission is granted to copy and distribute this case for non-commercial purposes, in both printed and electronic formats.
} 


\section{General Context}

With over 1000 companies in an area of just $2 \mathrm{~km}$ (CSO, 2016), the Sandyford Business District, in Dublin, [Exhibit 1] was one of the primary drivers of business and development in Ireland. However, due to the success of the area, the demand for services, and in particular public transport, had quickly outstripped the local public rail and bus capacity. Each day 30,000 employees and 5,000 residents are faced with up to an hour of congestion trying to enter and exit the district (CSO, 2016). Developing Sandyford as a smart city district was seen as a major goal for the district. Smart City development is an objective under the UN Sustainable Development Goal 11 which seeks to make settlements more resilient and sustainable (United Nations, n.d.). Smart cities are the urban center of the future, "made safe, secure environmentally green, and efficient because all structures - whether for power, water, transportation, etc. are designed, constructed, and maintained making use of advanced, integrated materials, sensors, electronics, and networks which are interfaced with computerized systems comprised of databases, tracking, and decision-making algorithms. "(Hall et al., 2000).

Workshop consultations with local district stakeholders, carried out in the summer of 2019, identified that mobility was the primary challenge facing the district. Smart technology-enabled solutions were sought to address this challenge, and the Smart Sandyford programme was established as a new initiative to develop Sandyford as a 'smart district'. The programme was a partnership between local government, higher education institutions, and local businesses. As the new Smart Dublin Coordinator for DLR, Ronan, [Exhibit 2] had been assigned with the objective of using technology to develop new research initiatives and projects to benefit the district.

The Smart Sandyford programme launched on the $27^{\text {th }}$ of February 2020, just two days before the first case of Covid-19 in Ireland was reported by the National Public Health Emergency Team (Irish Times, 2020). Ronan was faced with the challenge of developing the programme objectives and identifying what technologies could be deployed, tested and scaled to address the stated mobility objectives, while also contributing, and where possible reducing, the impacts of the virus in Sandyford. Ronan quickly realized that nothing was going to develop in this smart city district without the combined efforts of industry partners, communities, local government and higher education institutions together to prioritise research, project design and deployment of smart city technology solutions during a time of national crisis.

In the ten years prior to the launch of the Smart Sandyford programme, Sandyford itself had been transformed from an industrial estate with large warehouses and small-scale manufacturing to a modern business district with service-based companies establishing themselves in the area. While Sandyford was primarily a business district it also included complementary mixed-uses including residential, commercial, retail and open space. The Smart Sandyford programme aimed to develop projects that would enhance the district by addressing the challenges identified, thereby attracting investment and employment and providing residents with a sustainable living environment.

The Luas rail line connected Sandyford to Dublin City Centre, extending along Sandyford's northern boundary with three stations serving the district. The Luas is a light rail line and in high demand for Sandyford residents and workers. The Luas line was supplemented by four public bus routes, which utilised the internal road system within Sandyford. Despite this accessibility, the internal area within Sandyford was not well served by public transport. The district was also serviced by the M50 motorway on its southern boundary, which encouraged many of the commuters to drive to the district each day.

The digitalisation of public services at all levels of government had led to the need to test and validate new technologies. This resulted in the formation of Smart Dublin and the adoption of a Smart District approach. The Smart Sandyford district was the third smart district in Dublin [Exhibit 3]. Each district operated with a specific business objective: The first of these, in the Docklands, was designed as a Smart City testbed where developers could trial new sensors and connectivity designs. The second, Dublin City 
University (DCU) district, which included the 80,000 capacity Croke Park Stadium, was designed to interact as a smart campus to address challenges around mass movements and gatherings of people. Building on these earlier inceptions, Smart Sandyford was designed as a 'smart business district' to prioritise the needs of the business community and going beyond simple testing of devices to precommercial tests before city-wide deployment of technology.

The smart districts approach was designed based on the theory of a triple helix approach emphasising the need to combine the knowledge and experience of industry, academia, and government to successfully develop, trial and deploy smart technologies [Exhibit 4]. While each of the districts are directly supported by third level institutions and local government, Smart Sandyford was the first district to actively engage with industry through its partnership with the local companies in the district. Local companies were consulted monthly as part of the Smart Sandyford taskforce. The Smart Sandyford programme brought together four partner organisations: Trinity College Dublin through the Enable research programme, DLR, Smart Dublin and Sandyford Business Improvement District. See [Exhibit 5] for Smart Sandyford governance structure and partner description.

A number of industries, technologies and contrasting processes were involved in this case. Promoting alternative sustainable transport options including public transport, cycling, e-bikes, private buses and mobility hubs to name a few. The Smart Sandyford Programme sought to innovate not just through the deployment of new technology but also by working with council departments, higher education institutions and, local companies to educate and promote alternative approaches to everyday life. Once the initial objectives were agreed and everything was ready, the Programme launch was held on the $27^{\text {th }}$ of February 2020.

On the $29^{\text {th }}$ of February 2020, the first case of Covid-19 was confirmed in Ireland. On Thursday, $12^{\text {th }}$ March 2020, the government announced a series of measures aimed at addressing the outbreak of the virus. That evening, all schools and universities in Ireland were closed and any workers who could work from home were advised to do so. Over the coming days and weeks, the number of cases grew alarmingly. Almost all workers were working from home and the district was abandoned overnight. In many cases the initial projects that had been planned were no longer a priority, could not be progressed or were not appropriate. A new question was now added to the mix: What would be the impact of Covid-19 be on work practices in the future, and consequently on mobility requirements in cities?

\section{Specific Context}

In the summer of 2019, a series of workshops were carried out by the Smart Dublin team to establish the focus and challenges to be addressed by the Smart Sandyford programme. Priority challenges were identified, with the high level of traffic in the district featuring prominently. One of the core objectives for Smart Sandyford was to address the mobility challenges facing the district and the wider county.

As Sandyford transitioned from its industrial past, a number of legacy issues remain, not least of which included the poor connectivity between the various iterations of development areas. Previous projects had attempted to address the issue through a number of road alteration initiatives. Several junctions had been dug up, rebuilt and changed from roundabouts to traffic junctions but these measures had had little impact and, in some areas, had further impaired traffic wait times. In addition, there were many key sites still containing low rise industrial-type units, served by an internal road network ill-suited to pedestrian and cycle connectivity. While the Smart Sandyford programme did not have the power to change the building types, alternative transport innovations could be introduced. 
Working to address mobility challenges, the lack of baseline data was a primary concern for Ronan. His planned first step was to interact with the local stakeholders through surveys and workshops, and also to introduce sensors to monitor traffic and air quality to gather baseline data. The data from these sensors could then be used to decide on the next course of action and to convince the council and local business leaders to invest in new solutions and further research projects.

In addition, Ronan had long term plans for a series of mobility projects which could increase sustainable transport mode share and reduce unsustainable modes, in particular the use of private vehicles. Many of the planned projects focused on sustainable mobility and developing technologies to facilitate commuters to use public transport. These initiatives included provision of a smart shuttle bus, e-bike cycling and the aforementioned deployment of sensors to provide traffic monitoring and air quality measurement. Additionally, projects based on accessibility and climate monitoring were also considered. As a black swan event, the outbreak of Covid-19 could not have been planned for and caused almost insurmountable hurdles for the planned projects to progress.

With public, private and academic bodies involved on the project, the nature of the different partners meant that a number of different and sometimes conflicting aims and timelines were expected for the Smart Sandyford programme. A primary driver for the Council was the free flow of traffic and long-term reduction of congestion for commuters in the District, while the academic researchers were interested in research output and the value of data from the mobility projects, while the local companies wanted solutions to address immediate needs. However, all of the parties had a keen interest in the environmental impacts of transport and finding ways to alleviate this. These differences would require a high level of management and a structured approach to ensure the objectives of each partner could be addressed during the timeline of the programme. Regular weekly meetings were held with each of the partners, with additional monthly Smart Sandyford Taskforce meetings where the partners would meet to discuss the programme, including some technology companies based locally.

The management arrangement was further complicated by the necessity to introduce 'Work From Home' protocols in response to Covid-19. This meant that no employees were commuting to the district and the planned surveys, workshops and data gathering initiatives were no longer possible in the short term. This stood in the way of Ronan's early aims for the Smart Sandyford programme and managing different partners' expectations at this time was particularly challenging given the additional pressure associated with the virus. The partners had different approaches and timelines in terms of dealing with the virus and for office shutdowns; this meant that the early expectations for the programme varied greatly and a new approach would have to be agreed. Within two weeks of the initial outbreak the public bodies involved on the project were mandated to 'Work From Home' where possible. In particular, this presented a cultural challenge for DLR where staff did not previously have access to laptops or work programmes outside of DLR offices.

Following the onset of the virus it became clear that the crisis was the most important issue facing Sandyford. While the programme plan for Smart Sandyford could not have foreseen the impending disaster, it was designed to be flexible to deal with unexpected opportunities. The programme partners were quickly able to agree that while the mobility objectives set out from the community workshops were important, any effort that could help with the Covid-19 outbreak should be prioritized. This sentiment was given further backing as Sandyford became a hotspot for confirmed Covid-19 cases. Where possible, projects already in operation would continue, but if not Covid-19 related, these would be seen as a secondary task.

As the virus continued to infect more people the question became how to manage these rapidly changing circumstances and still achieve the programme objectives. Ronan was left with two core objectives: To 
carry on and progress the planned mobility projects as far as possible in the face of Covid-19; and where possible to address the impacts of the Covid-19 outbreak.

\section{District Framework for Mobility}

While the basic approach to Smart District development is Measure - Test - Deploy, this process is underpinned by five core 'pillars'. Using these five pillars provided Ronan with a straight forward and practical understanding of service needs, and promoted tech project deployments that added real value. The five pillars of the Smart District approach and their impact based on the virus are explained in [Exhibits 6-8].

In determining what mobility projects would most benefit the District, Ronan considered how mobility projects could be selected to address issues of contagion during times of crisis. He knew that he could learn from best practice globally in terms of the available technologies and then adapt these technologies for the local mobility issues. While these mobility challenges and the immediate impacts of Covid-19 were foremost in his mind, he was also aware of the inherent approach, in the Smart District, to resilience-based city design with respect to climate and economic shocks. The District approach to Smart City development was designed to be flexible and to incorporate innovative characteristics to enhance the local district and the greater Dublin area. Ronan identified that the Smart District could be used to shape the long-term sustainability of mobility projects for the city while helping with the response to curbing the spread of Covid-19.

With its major road and rail links, in addition to the relative density of its residential and commercial occupants, Sandyford was ideally located as a Smart District. The role of Smart Sandyford was to facilitate and enable the testing and trialling of smart city solutions that will not only improve the lives of those who live in the district, but also solutions that can scale across the city. The scalability of these solutions was particularly important and bringing together the universities and research centres, the tech and innovation ecosystem and the local councils, provides us with a unique mix of stakeholders that have the ability to transform Dublin as a smart urban region. The Smart District programme enables cities to truly think global but act local. By adapting learnings from global networks of smart cities researchers can quickly adapt and apply these learnings to the specific challenges facing these districts. In doing so, the feasibility of new technologies can be tested more quickly. This was achieved by building on the five pillars of the Smart District.

\section{Changing Political Landscape}

Covid-19 had immediate ramifications in terms of constrained resources in both the public and private sectors. As companies had their incomes cut, the Council rates fell to $20 \%$ of expected level since the outbreak. As a result, there was no additional funding for projects other than essential services. Also as a result of Covid-19, public transport services had to be cut with buses operating at $25 \%$ capacity. This reduced service level and the fear of using public transport among the public led to an expected increase in the number of single occupant cars driving to Sandyford. The initial groundwork for developing the mobility service case from the previous consultations was now outdated. These factors meant that a shared private bus operating in the district and other similar projects had to be pulled.

In times of crisis, Government and research schemes are often restricted as resources are redeployed and timelines constrained, which can result in projects focusing on cutting costs of current services rather than service innovation. Ronan knew that it was important to be able to test the mobility case using the district 
framework in Sandyford, to find details on the new challenges facing the area and how to address these, and to then make solutions available. However, each of these stages would take time he did not have. The Smart District approach needed time to get through its often long 'project tail'; Ronan's biggest fear was to alienate people who would only see the value a few years down the road, resulting in the programme losing support from the partners and stakeholders. Projects that scale may not optimise for the short-term return on investment or visual public presence, but by building the service and core service value then the programme could be validated in the long term.

Due to the limited resources available, Ronan had to be highly selective of which projects would be chosen. He was aware of several research projects which, although they looked good on paper, had not scaled to the city level and ultimately resulted in a report on a shelf. Given the circumstances Ronan sought to make the greatest impact with the limited resources available by focusing on network capability. It was within his remit to continue to enhance the basic Council services by ensuring that the network connectivity (Wi-Fi, IoT, telecommunications, etc.) would be available for new mobility solutions as necessary. While some of these communication networks were publicly managed, most relied on private operators. This would mean working with private network and infrastructure providers to ensure that regardless of what communication type was needed, the service would be available to the council, local business and citizens. "Essentially we have a collaboration model where we as the city can act as the independent voice and broker," Ronan said. "Cities need to be at the heart of that, to shape the application of emerging technologies in a way that benefits the city and its citizens." This approach would require overcoming cultural challenges in working with outside partners which would complicate the projects and blur the line between public service and private enterprise.

\section{Decision Summary}

Following the Smart Sandyford launch and with the programme now up and running, Ronan and his team needed to make a decision on how to progress and the best way to deliver mobility projects for Sandyford. In the first instance, any projects that were underway were reviewed for how they could be adapted to help fight Covid-19. A refined version of the district project funnel [Exhibit 9] was used to quickly analyse the possibilities and benefits of potential projects. These projects were subsequently analysed for their alignment with the Smart Dublin ethics and data management protocols.

Due to the restricted resources and person power available to him, Ronan was left with three main options: (1) A short-term quick win; (2) Facilitating the market to deliver solutions; or (3) Gathering data and developing a more long-term project strategy:

1. E-bikes for frontline medical staff: It became clear that medical staff were some of the most at-risk populations who needed to be protected from the virus. The presence of the Beacon and Leopardstown Park hospitals in the district meant that finding ways to help front line healthcare professionals could be a visible way for Smart Sandyford to help during the crisis. The shortage of public transport options and the fear of using family vehicles among medical staff meant that alternative modes of transport were needed for them to commute. One project in particular stood out as an obvious option to address this challenge: An e-bike trial with mobility company Moby, which had been scheduled for the summer was ideal for its simplicity and clear service value to the frontline medical staff. Following initial consultations between Moby and DLR it was agreed that the ebikes that were to be deployed in the district, could be redeployed to frontline staff. The DLR mobility hub, which is a shared car and bike scheme for Council staff, could also provide their fleet of e-bikes for this cause. These two e-bike fleets could be combined and redeployed for the frontline hospital workers who did not want to use reduced public transport, helping them get to work and minimising single driver car use in the district. 
2. Focus on exploring connectivity and allow the market to provide solutions: As the virus infected more countries around the world it became clear that communication and measurement of different responses would need to be analysed. Ronan's team formed part of an international collaborative research network who came together to research strategies to prevent the spread of, and eventually eradicate Covid-19 across different regions and specific countries. In the initial weeks of the outbreak a number of online workshops were held with these experts to discuss what technologies were available, how were they deployed, how information was communicated with the local populous and what technologies were being used to monitor the spread. Following this research, it was clear that projects informing the public of the impacts and the measures to curtail Covid-19, as well as projects for contact tracing and other communication-based projects, were critical. Ronan could work with the public infrastructure providers to ensure any available information and contract tracing solutions would be funded and made available to the general public.

3. Capital investment option: As the Work From Home protocols were enforced, much of the District became deserted. A more long-term plan was proposed that could monitor the changing demand for transport modes in the District and to then be able to capitalise on shifting trends. In order to monitor such changing trends, a three-pronged data gathering project was envisaged, which could monitor traffic, air quality and employee sentiment in the district. A sensor-based analysis of transport demands could include traffic counting and air quality sensors. These sensors could be combined with qualitative public surveys and infrastructure providers' mobility data sets. This combination of data types would give an overview of mobility in the District and paint a more vivid picture of what was really going on for decision-makers across each of the partner groups. Traffic counting sensors, which were deployed to monitor the congestion in the area, could now be reworked to monitor the volume of employees returning to work in the district. Ronan's mantra of "Measure - Test - Deploy" would allow the Council to respond to changing demands among the local population.

\section{References}

CSO (2016). Central Statistics Office, Census 2016. Retrieved from https://www.cso.ie/en/csolatestnews/presspages/2017/census2016summaryresults-part1/

United Nations (n.d.) Goal 11 | Department of Economic and Social Affairs. Retrieved from https://sdgs.un.org/goals/goall 1

Hall, R.E., Bowerman, B., Braverman, J., Taylor, J., Todosow, H. and Von Wimmersperg, U., (2000). The vision of a smart city (No. BNL-67902; 04042). Brookhaven National Lab., Upton, NY (US).

Irish Times (2020), Coronavirus Timeline in Ireland. Retrieved from https://www.irishtimes.com/news/health/coronavirus-timeline-the-cases-confirmed-in-ireland-so$\underline{\text { far- }-1.4195178}$

\section{Acknowledgements}

The authors wish to acknowledge the Fulbright Commission and Lero Science Foundation Ireland for their support of the Fulbright Core Research Award that supported Dr. Mullarkey's work with Dublin City Council, National University of Ireland Maynooth, and Trinity College Dublin. 


\section{Exhibit 1: Sandyford Business District}

Sandyford Business District (SBD) had the same administrative area as Smart Sandyford. SBD contains the four business parks:

1. Central Park

2. Sandyford Business Park

3. South County Business Park

4. Stillorgan Business Park

The district is a Strategic Development Zone within DLR in Dublin, see map:

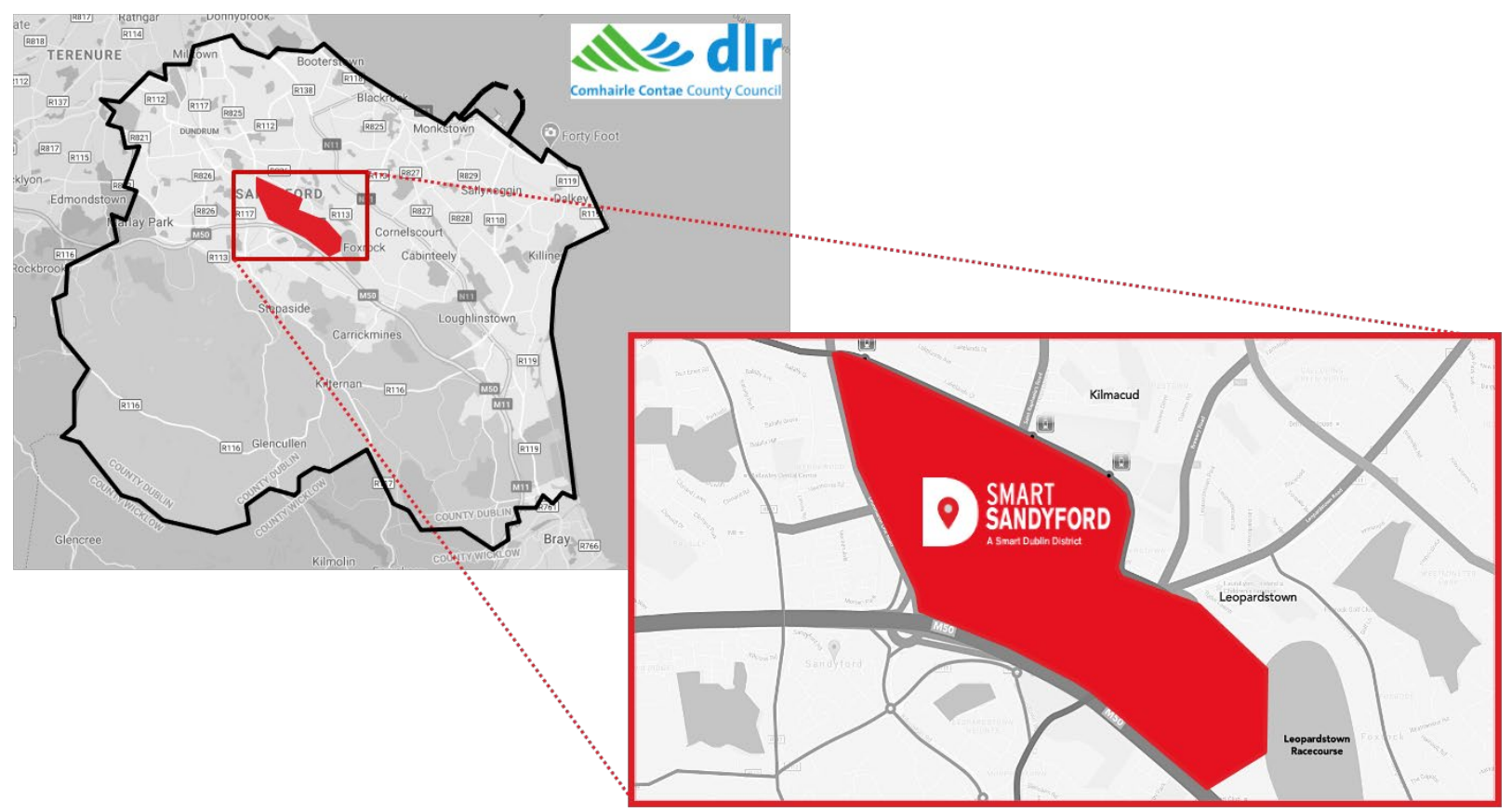




\section{Exhibit 2: Ronan Herron, Smart Dublin Coordinator for DLR}

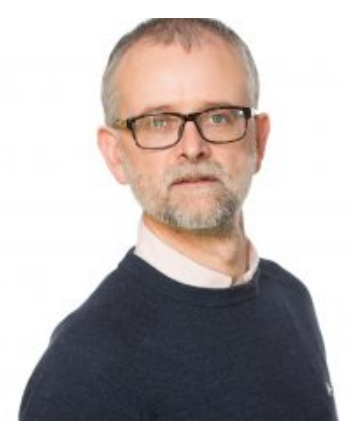

Working as Digital Strategy Officer for DLR, Ronan had 12 years' experience in the Local Authority sector and over 20 years' experience in ICT. An initial interest in Open Source Software led to his working in the areas of ICT in Education, mapping in the Public Sector and the role of technology and data in transforming local government through improved efficiencies and transparency.

Since starting with DLR in 2016 Ronan had been involved in various projects under the Digital Transformation banner, including defining and delivering the technology solution for the new Council Chamber, the development and delivery of DLR's new customer care centre - The Civic Hub, the digitisation of the DLR Grants System and the Smart Dublin SBIR IoT (Internet of Things) Challenge.

Ronan's primary degree is in Philosophy and English, he also has a Postgrad in Communications and various other professional qualifications including Linux, Microsoft, Python and Welding. 


\section{Exhibit 3: Geography of Smart Dublin Districts}

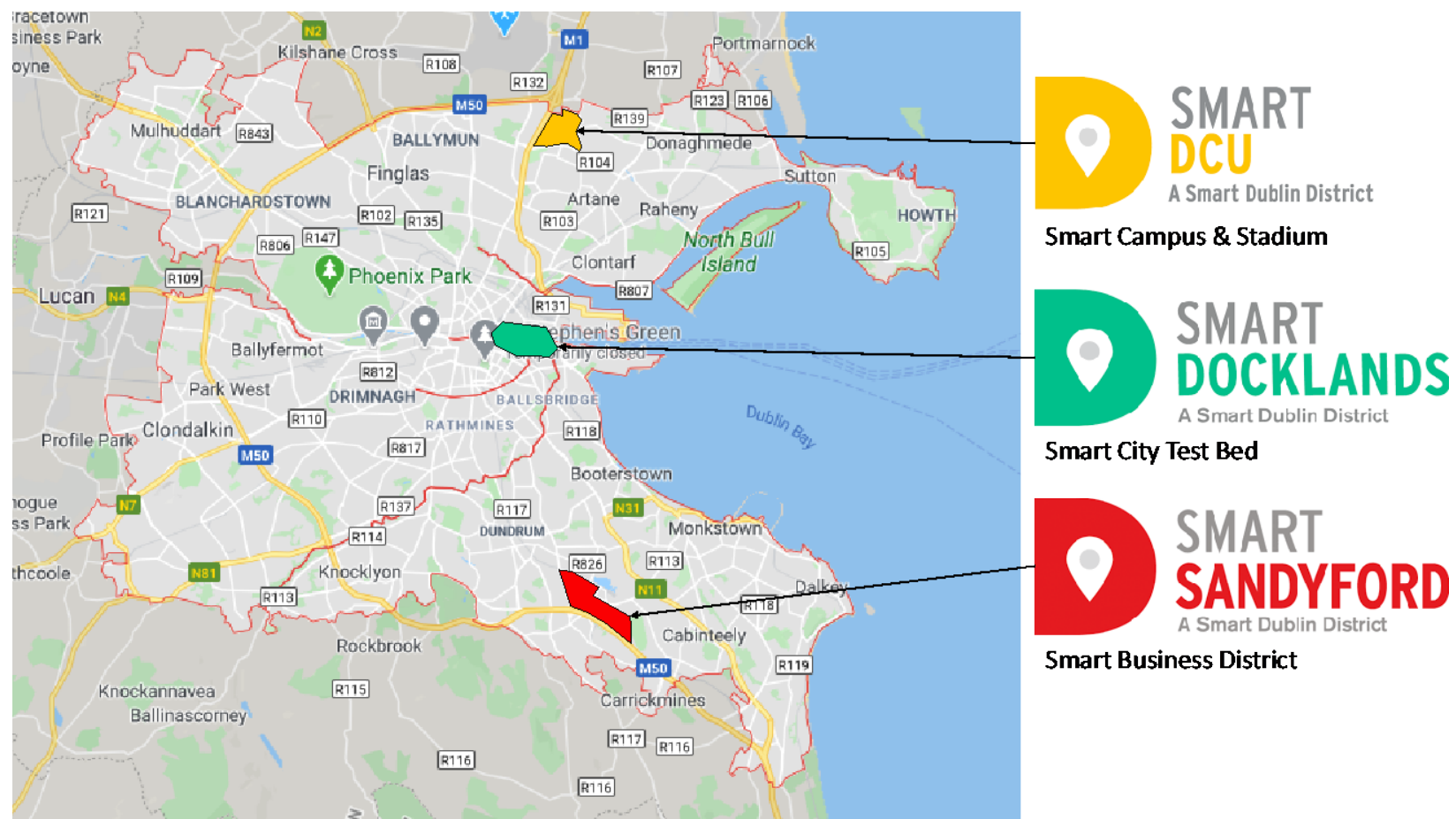




\section{Exhibit 4: Triple \& Quadruple Helix Models}

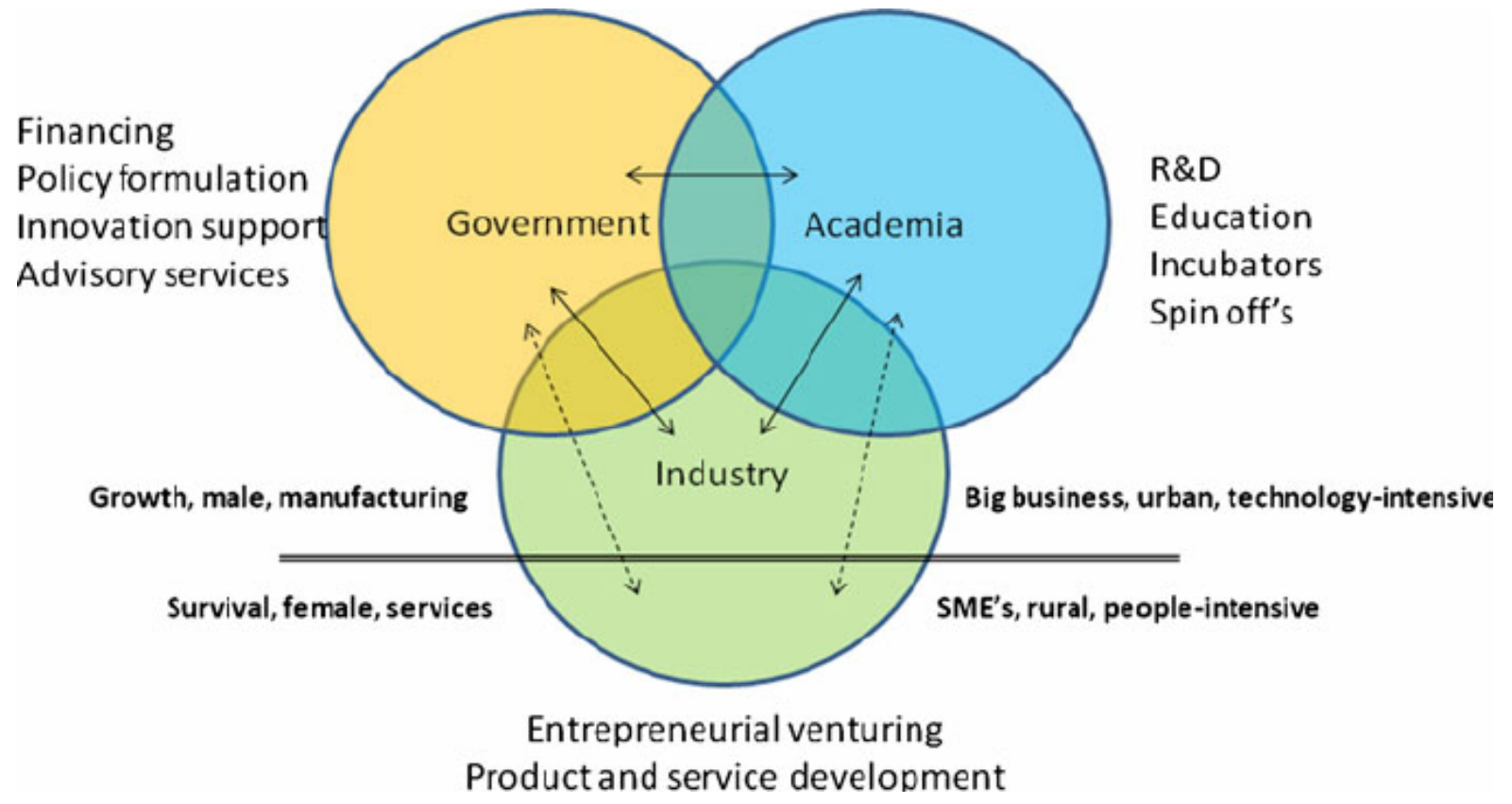

(Lindberg \& Lindgren, 2014)

Source: Lindberg, M., Lindgren, M. and Packendorff, J., 2014. Quadruple Helix as a way to bridge the gender gap in entrepreneurship: the case of an innovation system project in the Baltic Sea region. Journal of the Knowledge Economy, 5(1), pp.94-113.

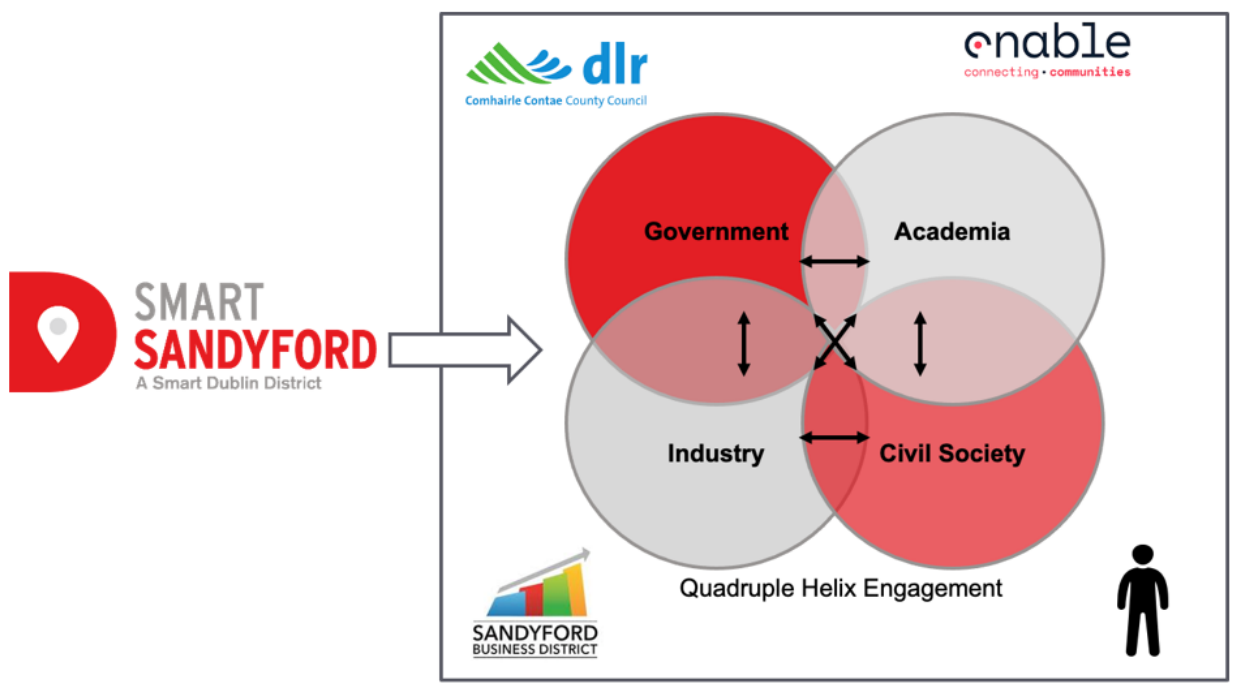




\section{Exhibit 5: Smart Sandyford Governance Structure}

Trinity College Dublin (TCD): the Enable programme was a Science Foundation Ireland research spoke which carries out research as part was addressing the challenges that currently limit the potential benefits of IoT for communities. This involves a focus on enabling smarter buildings, more efficient transportation, better handling of environmental issues, stronger data privacy, and enhanced cyber and infrastructure security. Enable supported the Smart Sandyford programme to allow their technology to be deployed outside the laboratory in smart districts. These district testbeds allow Enable to combine, assess and evaluate results from as real-world environment exemplars. Professor Siobhán Clarke was the Principal Investigator of Enable with responsibility for the Smart Sandyford programme. Enable funded 50\% of the Smart Sandyford programme and managed the administration of the programme.

Dún Laoghaire Rathdown County Council (DLR): The Digital Transformation team led by Ronan Herron in conjunction with the Economic and Development Officer, Owen Laverty, were tasked with updating how DLR embraces digital technologies to enhance their own activities in order to grow and expand. The Smart Sandyford programme required close links with each of the DLR departments to facilitate projects and to ensure correct procedures were followed. DLR funded 50\% of the Smart Sandyford programme.

Smart Dublin: Smart Dublin was an initiative of the four Dublin Local Authorities to engage with smart technology providers, researchers and citizens to solve challenges and improve city life. Their objective was to position Dublin as a world leader in the development of new urban solutions, using open data, and with the city region as a testbed. Smart Dublin had identified mobility, climate change, and emergency management as priority challenges. Smart Sandyford was the third Smart Dublin District each of which have their own unique objectives. Alan Murphy was the Smart Dublin Lead, and Aishling Lennon was the Regional Coordinator.

Sandyford Business Improvement District CLG (SBID): The Smart Sandyford programme also partnered with SBID as a local business representative organisation to promote relationships with technology companies in Sandyford. A range of companies had direct input to project selection including company representatives on the SBID Board, and the Smart Sandyford Taskforce which met monthly to discuss projects. 


\section{Exhibit 6: Smart District 5 Pillars}

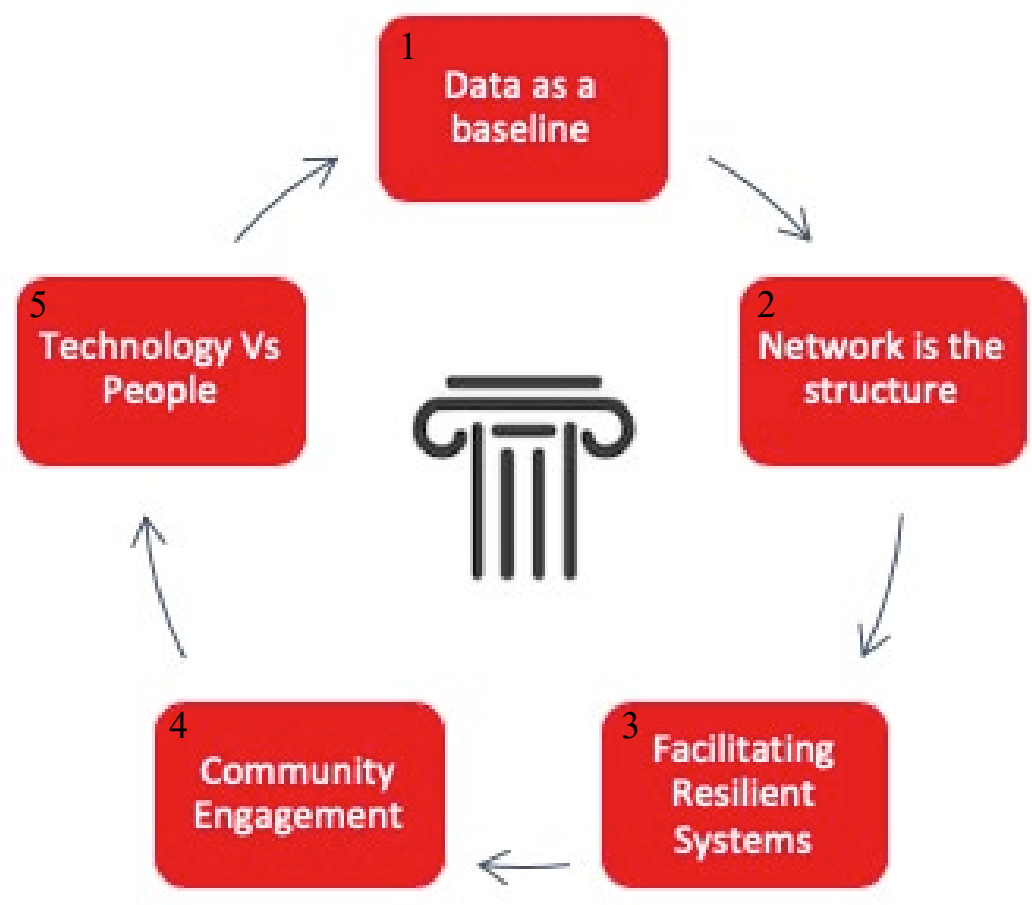

\section{Data as a baseline}

Establishing threshold levels of traffic levels, air quality, service quality and the attitudes of the local population are key in establishing what interventions (if any) should be made. In terms of public transport Sandyford was serviced by public bus routes and the Luas light rail tram which crosses the road network at two of the main entry points and was operating at capacity at this time creating further delays each day. Ronan was tasked with introducing baseline measurements of the traffic in the area and introducing technology-based solutions and projects to improve the situation.

\section{2.}

\section{The Network was the Structure}

Enhancing local networks was a key part of the district approach, this was the backbone of communications and the success of the city was the ability for its citizens and objects to communicate. While the primary communication types include Wi-Fi, LPWAN, $5 \mathrm{~g}$, and Bluetooth a full range of the various communication types used to build smart cities can be seen in [Exhibit 7]. Often these networks are generally similar in their function but have specific strengths and weaknesses depending on the use case. The challenge for local government was knowing which networks to invest in for the long term. Implementing these network infrastructures requires resources from across organisations, indeed in this case the testing of LPWAN technology LoRa in Dublin was largely developed by Pervasive Nation a TCD research programme. The cost and complexity associated with these varied networks means that the 
triple helix approach adopted by the districts was necessary to be able to deploy a variety of network types. Working within the triple helix and using a mixture of private and public networks had a number of advantages:

a) Facilitates sharing of information between partners

b) Consolidates services, minimising clutter

c) Ensures competitive service offerings for end users

\section{3. $\quad$ Facilitating Resilient Systems}

As detailed earlier the Smart District approach aims to enhance the resilience of the urban environment to economic and environmental shocks [See Exhibit 8]. This can be achieved through projects that promote flexibility and redundancy within the system. As with Covid-19 these kinds of black swan, shock events cannot be reasonably planned for and so require contingency options that can be relied upon when primary systems are not functioning. In the first instance, infrastructure analysis and asset mapping was key to understanding what exists within the system. Often these complex communication networks are not mapped in any one location. Analysing what these assets are, how they work and communicating this with key decision makers was a critical first step.

\section{Community Engagement}

The Smart District engagement pillar was used to identify the mobility challenges of those who live in the district, and to identify possible mobility solutions which could be developed and deployed. Feedback from the companies, employees and residents would be essential to monitor the impact these solutions have for the inhabitants. In this case consultation with local companies and residents was held before the launch of the programme. The local companies were also able to give feedback to the programme through the Smart Sandyford Taskforce which met monthly. Workshops and webinars were also useful tools to ensure that feedback was not just a tick box exercise at the beginning of projects but rather a constant feedback loop throughout the project's duration. In some Smart District approaches community engagement is envisaged as an expansion on the triple helix approach, adopted here, to form a quadruple helix.

\section{Technology Vs People}

Technology was a means to enhancing people's lives and not an end in and of itself. The fifth pillar was an important element of each and every Smart District project and this essentially means that the project must benefit the inhabitants of the local district first, whether this be directly through new transport modes or indirectly though enhanced service provision. Data management in particular was a critical issue for any smart city and the aim of the smart districts was to manage data in such a way as to have the data open, transparent and publicly visible wherever possible. The Dublinked data platform offers a central location for citizens to see the data from each of the districts and from other sources across the city. This goes beyond the legal requirements set down in law through General Data Protection Regulation, GDPR, but also analyses the ethical correctness of each project. 
Exhibit 7: Smart City Technologies

\begin{tabular}{|c|c|c|c|c|c|}
\hline $\begin{array}{c}\text { Communi- } \\
\text { cation } \\
\text { Technology }\end{array}$ & $\begin{array}{c}\text { Standard/ } \\
\text { governing } \\
\text { bodies }\end{array}$ & Frequency & $\begin{array}{l}\text { Range } \\
\text { (app.) }\end{array}$ & Data rates & Topology \\
\hline $\mathrm{NFC}$ & $\begin{array}{l}\text { ISO/IEC - } \\
\text { ISO } 13157 \text { etc. }\end{array}$ & (HF) $13,56 \mathrm{MHz}$ & $10 \mathrm{~cm}$ & $\begin{array}{l}106,212,424 \\
\text { Kbps }\end{array}$ & Point-to-point \\
\hline RFID & $\begin{array}{l}\text { ISO/IEC - } \\
\text { ISO/IEC } \\
18000\end{array}$ & $\begin{array}{l}\text { (LF) } 125-134 \\
\mathrm{kHz} \\
(\mathrm{HF}) 13.56 \mathrm{MHz} \\
(\mathrm{UHF}) 856-960 \\
\mathrm{MHz}\end{array}$ & $\begin{array}{l}3-10 \mathrm{~m} \\
\text { (active } \\
\text { up to } \\
100 \mathrm{~m} \text { ) }\end{array}$ & $\begin{array}{l}40 \mathrm{Kbps}-640 \\
\mathrm{~K}\end{array}$ & Point-to-point \\
\hline $\begin{array}{c}\text { Bluetooth/ } \\
\text { Bluetooth } \\
\text { Low } \\
\text { Energy } \\
\text { (BLE) }\end{array}$ & $\begin{array}{l}\text { IEEE 802.15.1/ } \\
\text { Bluetooth SIG }\end{array}$ & $2.4 \mathrm{GHz}$ & $\begin{array}{c}10 \mathrm{~m} \\
\text { typical } \\
30-50 \mathrm{~m} \\
\text { (BLE) }\end{array}$ & $\begin{array}{l}\text { 1-3 Mbps } \\
1 \mathrm{Mbps} \\
\text { (BLE) }\end{array}$ & $\begin{array}{l}\text { Point-to- } \\
\text { point, } \\
\text { Piconet, } \\
\text { Scatternet, } \\
\text { Star-bus } \\
\text { (BLE) }\end{array}$ \\
\hline Z-Wave & $\begin{array}{l}\text { Z-Wave } \\
\text { Alliance } \\
\end{array}$ & $900 \mathrm{MHz}$ & $\begin{array}{c}30 \mathrm{~m} \text { (ind.) } \\
100 \mathrm{~m}\end{array}$ & 9,6-100 kbps & $\begin{array}{c}\text { Star, cluster, } \\
\text { mesh }\end{array}$ \\
\hline ZigBee & $\begin{array}{l}\text { ZigBee } \\
\text { Alliance } \\
\end{array}$ & $2,4 \mathrm{GHz}$ & $\begin{array}{l}10-100 \\
\mathrm{~m} \\
\end{array}$ & $250 \mathrm{~kb} / \mathrm{s}$ & Mesh \\
\hline WiFi & $\begin{array}{l}\text { IEEE } 802.11 \\
(\mathrm{a} / \mathrm{b} / \mathrm{g} / \mathrm{n})\end{array}$ & $\begin{array}{l}2,4 / 3,6 / 4,9 / 5 / 5,9 \\
\mathrm{GHz}\end{array}$ & $100 \mathrm{~m}$ & $1-54 \mathrm{Mbps}$ & Star \\
\hline $\begin{array}{c}\text { ULP } \\
(802.15 .4 q)\end{array}$ & $\begin{array}{l}\text { IEEE Std } \\
802.15 .4 \mathrm{q} \\
\end{array}$ & $\begin{array}{l}868 / 915 / 2450 \\
\mathrm{MHz}\end{array}$ & $100 \mathrm{~m}$ & $100 \mathrm{kbps}$ & Star \\
\hline \begin{tabular}{|c|} 
VI-SUN 1606 \\
$(802.15 .4 \mathrm{~g})$ \\
\end{tabular} & $\begin{array}{l}\text { Wi-SUN } \\
\text { Alliance } \\
\end{array}$ & \begin{tabular}{|l} 
sub-1 GHz, \\
$2,4 \mathrm{GHz}$ \\
\end{tabular} & $200 \mathrm{~m}$ & $1 \mathrm{Mpbs}$ & $\begin{array}{l}\text { Star, Mesh, } \\
\text { Peer-to-peer }\end{array}$ \\
\hline 6LoWPAN & $\begin{array}{l}\text { Internet } \\
\text { Engineering } \\
\text { Task Force } \\
\text { (IETF) } \\
\text { IETF } \\
\text { RFC4944 } \\
\end{array}$ & $\begin{array}{l}868 \mathrm{MHz} / \\
915 \mathrm{MHz} / \\
2,4 \mathrm{GHz}\end{array}$ & $200 \mathrm{~m}$ & $\begin{array}{l}250 \mathrm{kbps} \\
(2,4 \mathrm{GHz}) \\
40 \mathrm{kbps} \\
(915 \mathrm{MHz}) \\
20 \mathrm{kbps} \\
(868 \mathrm{MHz}) \\
\end{array}$ & $\begin{array}{l}\text { Node-to- } \\
\text { node, Star, } \\
\text { Tree, Mesh }\end{array}$ \\
\hline $\begin{array}{l}\text { Wireless } \\
\text { M-BUS }\end{array}$ & EN $13757-4$ & $\begin{array}{l}169 / 433 / 868 \\
\mathrm{MHz} \\
\end{array}$ & $300 \mathrm{~m}$ & $\begin{array}{l}2,4 \text { kbps- } 100 \\
\text { kbps }\end{array}$ & Star \\
\hline $\begin{array}{c}\text { WiFi Low } \\
\text { Power } \\
(802.11 \mathrm{ah})\end{array}$ & $\begin{array}{l}\text { IEEE } 802.11 \\
\text { working group }\end{array}$ & Sub-1 GHz & $1 \mathrm{~km}$ & $\begin{array}{l}\text { 150kbps } \sim \\
346,666 \mathrm{Mbps}\end{array}$ & Star, Tree \\
\hline Weightless-W & $\begin{array}{l}\text { Weightless } \\
\text { Special Interest } \\
\text { Group (SIG) }\end{array}$ & $\begin{array}{l}470-790 \mathrm{MHz} \\
\text { TV white spaces }\end{array}$ & $5 \mathrm{~km}$ & \begin{tabular}{|l|}
$250 \mathrm{~b} / \mathrm{s}-50$ \\
$\mathrm{~kb} / \mathrm{s}(\mathrm{UL})$ \\
$2.5 \mathrm{~kb} / \mathrm{s}-16$ \\
$\mathrm{Mb} / \mathrm{s}(\mathrm{DL})$ \\
\end{tabular} & Star \\
\hline Weightless-N & $\begin{array}{l}\text { Weightless } \\
\text { Special Interest } \\
\text { Group (SIG) } \\
\end{array}$ & Sub GHz (ISM) & $3 \mathrm{~km}$ & $\begin{array}{l}250 \mathrm{~b} / \mathrm{s}(\mathrm{UL}) \\
\text { None (DL) }\end{array}$ & Star \\
\hline Weightless-P & $\begin{array}{l}\text { Weightless } \\
\text { Special Interest } \\
\text { Group (SIG) }\end{array}$ & Sub GHz (ISM) & $2 \mathrm{~km}$ & $\begin{array}{l}200 \text { bps-100 } \\
\text { kbps (UL) } \\
200 \text { bps-100 } \\
\text { kbps (DL) } \\
\end{array}$ & Star \\
\hline
\end{tabular}


DOWLING, MULLARKEY, CLARKE

\begin{tabular}{|c|c|c|c|c|c|}
\hline $\begin{array}{c}\text { Communi- } \\
\text { cation } \\
\text { Technology }\end{array}$ & $\begin{array}{c}\text { Standard/ } \\
\text { governing } \\
\text { bodies }\end{array}$ & Frequency & $\begin{array}{l}\text { Range } \\
\text { (app.) }\end{array}$ & Data rates & Topology \\
\hline $\begin{array}{c}\text { LTE-M } \\
\text { Release } \\
12 / 13\end{array}$ & $\begin{array}{c}\text { 3GPP Release } \\
12\end{array}$ & $700-900 \mathrm{MHz}$ & $2,5-5 \mathrm{~km}$ & $\begin{array}{c}200 \mathrm{kbps} \\
\text { (DL) } \\
200 \mathrm{kbps} \\
\text { (UL) }\end{array}$ & Star \\
\hline $\begin{array}{l}\text { DASH7 } \\
1606\end{array}$ & $\begin{array}{l}\text { DASH7 } \\
\text { Alliance }\end{array}$ & $\begin{array}{c}\text { SUB-GHz } \\
433 / 868 / 915 \\
\mathrm{MHz} \\
\end{array}$ & $5 \mathrm{~km}$ & $\begin{array}{c}9.6,55.6,166.7 \\
\text { kbps }\end{array}$ & $\begin{array}{c}\text { Node-to- } \\
\text { node, Star, } \\
\text { Tree, Mesh }\end{array}$ \\
\hline LoRaWAN & LoRa Alliance & $\begin{array}{c}433,863-870 \\
\mathrm{MHz} \\
\text { (EU) } \\
902-928 \mathrm{MHz} \\
\text { (US) }\end{array}$ & $2-15 \mathrm{~km}$ & $\begin{array}{c}250 \text { bps- } 50 \\
\text { bps (UL EU) } \\
250 \text { bps- } 50 \\
\text { kb/s (DL EU) }\end{array}$ & Star \\
\hline SigFox & SigFOX & $868-902 \mathrm{MHz}$ & $\begin{array}{c}10-50 \\
\mathrm{~km}\end{array}$ & \begin{tabular}{|l}
256 b/day \\
(DL), \\
$\leq 100$ bps \\
(UL) \\
\end{tabular} & Star \\
\hline LTE & $3 \mathrm{GPP}$ & $2,5 / 5 / 10 \mathrm{GHz}$ & $30 \mathrm{~km}$ & $\begin{array}{l}300 \mathrm{Mbps}(\mathrm{DL}) \\
75 \mathrm{Mbps}(\mathrm{UL})\end{array}$ & Star \\
\hline LTE-A & $3 \mathrm{GPP}$ & $\begin{array}{l}2,5 / 5 / 10 / 15 / 20 \\
\mathrm{GHz}\end{array}$ & $30 \mathrm{~km}$ & $\begin{array}{l}\text { 1Gbps(DL),5 } \\
00 \mathrm{Mbps}(\mathrm{UL})\end{array}$ & Point-to-point \\
\hline WiMAX & $3 \mathrm{GPP}$ & $3,5 \mathrm{GHz}$ & $50 \mathrm{~km}$ & $75 \mathrm{Mbps}$ & $\begin{array}{l}\text { Point-to- } \\
\text { multipoint, } \\
\text { mesh }\end{array}$ \\
\hline Ingenu & Ingenu & $\begin{array}{l}2450 \mathrm{MHz} \\
\text { (ISM) }\end{array}$ & $100 \mathrm{~km}$ & \begin{tabular}{|l|}
$624 \mathrm{kbps}$ \\
(UL) \\
$156 \mathrm{kbps}$ \\
(DL) \\
\end{tabular} & Star. Tree \\
\hline NB-IoT & $\begin{array}{l}\text { 3GPP Release } \\
13\end{array}$ & $\begin{array}{l}\text { Can be deployed } \\
\text { in } 2 \mathrm{G} / 3 \mathrm{G} / 4 \mathrm{G} \\
\text { spectrum (e.g. } \\
450 \mathrm{MHz} \text { to } \\
3.5 \mathrm{GHz} \text {, }\end{array}$ & $\begin{array}{l}1 \mathrm{~km} \\
\text { (urb.) } \\
10 \mathrm{~km} \\
\text { (rur.) }\end{array}$ & $\begin{array}{l}234,7 \mathrm{kbps} \\
\text { (DL) } \\
204,8 \mathrm{kbps} \\
\text { (UL) }\end{array}$ & - \\
\hline EC-GSM & $\begin{array}{l}\text { 3GPP Release } \\
13\end{array}$ & $800-900 \mathrm{MHz}$ & $15 \mathrm{~km}$ & $\begin{array}{l}\sim 300 \mathrm{kbps} \\
(\mathrm{DL}) \\
10 \mathrm{kbps}(\mathrm{UL}) \\
\end{array}$ & - \\
\hline CS IoT & - & $700-900 \mathrm{MHz}$ & - & $\begin{array}{l}200 \mathrm{kbps} \\
\text { (DL) } \\
\sim 48 \mathrm{kbps} \\
\text { (UL) } \\
\end{array}$ & - \\
\hline
\end{tabular}

Source: Dobrilović, D. (2018). Networking Technologies for Smart Cities: An Overview. Interdisciplinary Description of Complex Systems: INDECS, 16(3-A), pp.408-416 


\section{Exhibit 8: The Resilience Curve}

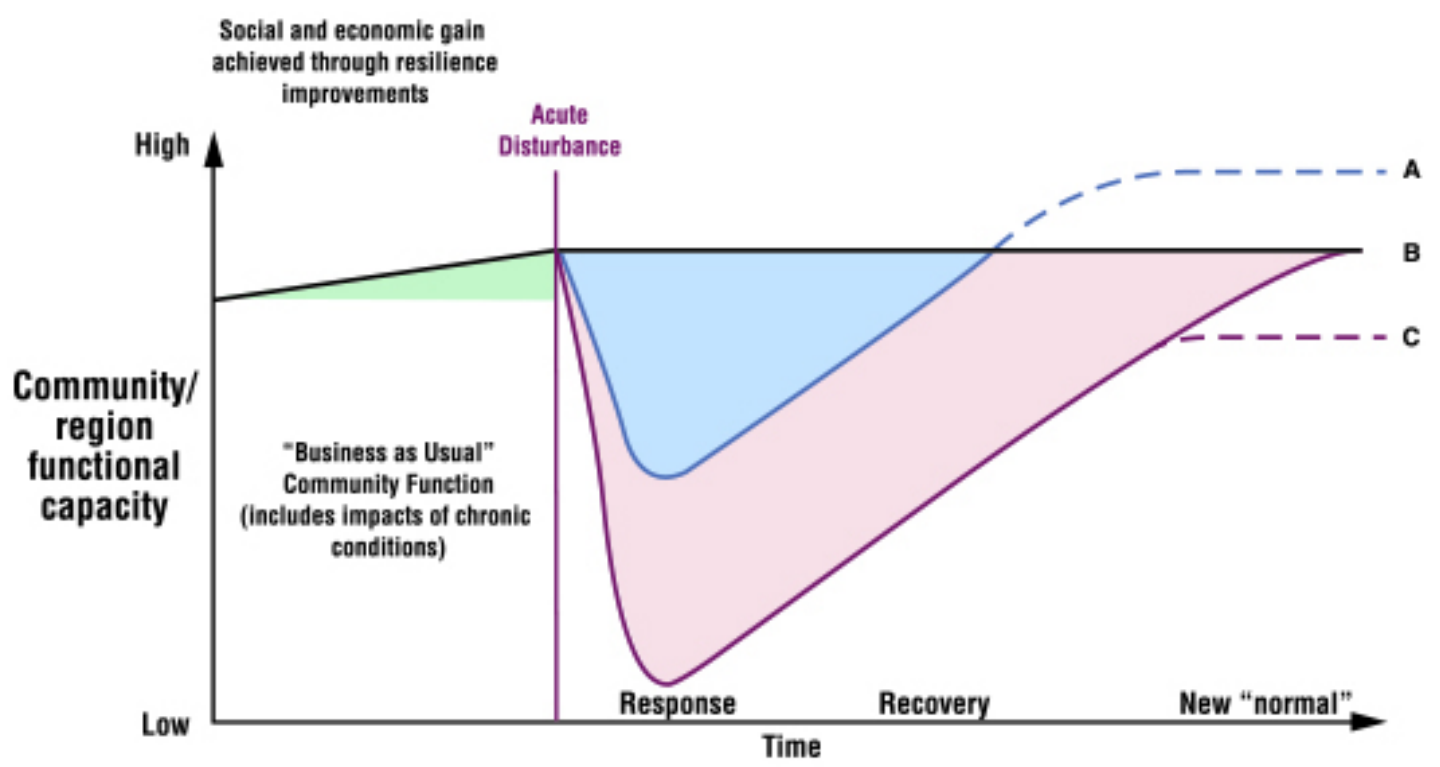

Source: White et al. (2015), p. 203 Adapted from model developed by M.E Hynes, B. Ross, and CARRI (2008), presented at the DHS University Summit, Washington, DC 


\section{Exhibit 9: District Project Funnel}

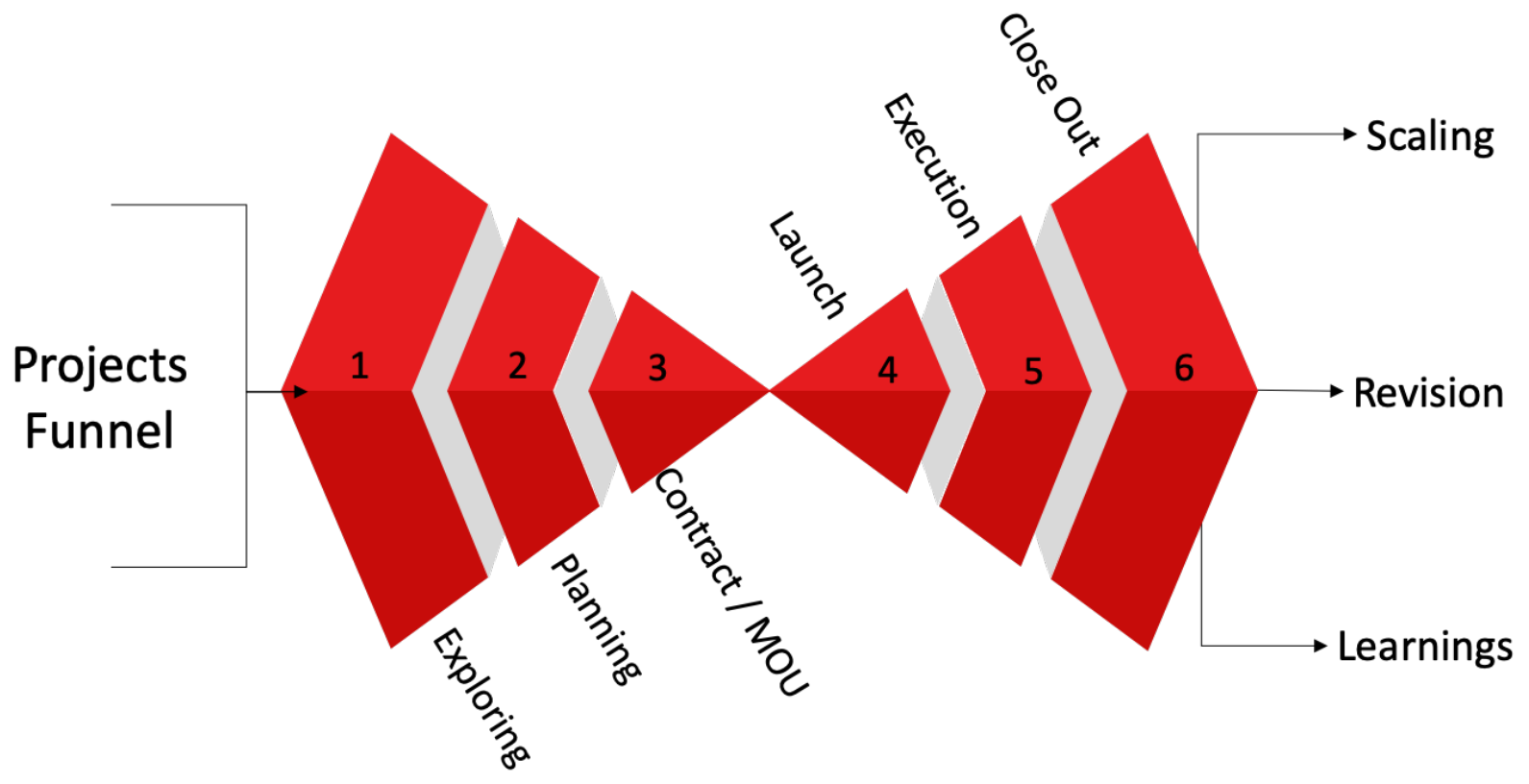

